\title{
Research on the Construction of College Students' Online Entrepreneurship Platform
}

\author{
(SUBMITTED BUT NOT PRESENTED) \\ JIANG Yi \\ (Economics and Management Experimental Teaching Center, Chongqing Technology and Business University, \\ Chongqing,400067,China) \\ 1053997536@qq.com
}

\begin{abstract}
Along with the transformation of China's economic structure and the popularization of mass education, the employment situation of university students is becoming grimmer. As an ideal way for university students to take up an occupation, the entrepreneurship has become the focus of attention to the government, society and university. However, there are some problems that need to be solved. Starting from the cultivation of university students' innovation consciousness, the construction of online venture platform could create business atmosphere, implement entrepreneurship education, link up the entrepreneurs and firms, and bring about the comprehensive development of university students' entrepreneurship.
\end{abstract}

Keywords - college students, entrepreneurship, platform, education

\section{THE BACKGROUND OF COLLEGE STUDENT S' ENTREPRENEURSHIP}

In recent years, under the guidance of central policy and the change of the environment of economics and society, entrepreneurship has become one of the important employ ment choices for graduates. Thus, entrepreneurship for graduates has been in the active period.Graduates would have achieved a great career if they could seize the opportunities under the background of entrepreneurship.

\section{A. The grim employment situation}

After successfully completing studies, most of university students face with the choice of employment. The development of economy and society has greatly changed the employment situation of university students. First, after 30 years of rapid growth, China's comprehensive economic strength leapt to the forefront of the world, with significantly enhancing the level of science and technology and unceasingly strengthening the intemational competitiveness of firms. All above promote the continuous optimization of the industrial structure, constantly upgrade the traditional manual industry, develop the intensive technology industry and weaken the demand of employment. Secondly, after the rapid growth, Chinese economy faces with the growth shift which will inevitably give employ ment growth to some pressure. Finally, the number of college graduates is growing rapidly.According to the information released by China Education Online, the popularization of mass education in universities leads to the increase of graduates from 1140000 in 2001 to 7490000 in 2015[1]. The factors that have changed the state where the state and government offer jobs for graduates include the adjustment of economic structure, the transition of industrial structure and the growth of the number of university graduates. So, the employment pressure increases for the university students.

\section{B. The unprecedented entrepreneurship opportunity}

The new time give students the chance of entrepreneurship. First, the government, with the society and universities pays attention to university students' entrepreneurship, formulates a series of preferential policies and measures to assist, and relieves taxation, funding and charges considerably. Taking Chongqing for an example, it is made clear in the plan of support mechanism and implementation for Chongqing small micro enterprise (The Chongqing municipal government[2014] 36) that the support mechanism of the small and micro firms has been listed in the $25 \mathrm{key}$ reform projects. The government has formulated a series of policies to support micro firms, reduce the costs of entrepreneurship and stimulate creativity. To strengthen the industry guidance, support policies stipulate that the micro firms, that are founded in area of five municipal encourage innovation (such as science and technology, electronic commerce, energy conservation and environmental protection, cultural and creative, and agriculture) and the encouraged industry of the county, can apply for less than 5 million yuan start-up grants (formerly financial subsidies) and a maximum of 15 million yuan of business support loans after two months of the registration. At present, the entrepreneurship of university graduates in Chongqing can obtain the maximum subsidy of up to nearly 240000[2]. Secondly, with the rapid development of the internet, its users grow rapidly. As of June 2014, the 34th 'China Internet development statistics report' released by CNNIC showed that the scale of China's Internet users had reached 6.32 billion, with the increase of 1442 million compared with the end of 2013 , internet penetration rate was $46.9 \%$. So, online entrepreneurship has become one direction of university students' entrepreneurship. The diversification of entrepreneurship channels not only encourages university students to achieve the real entrepreneurship, but also online entrepreneurship.

\section{THE GENERAL SITUATION AND MAIN PROBLEMS OF COLLEGE ST UDENTS' ENTREPRENEURSHIP}

The entrepreneurship of graduates has become the focus of the whole society. However,only when the main problems below get solved,can the entrepreneurship of graduates develop healthily. 


\section{A. The college students' entrepreneurial desire is stronger, but less actual business}

Entrepreneurship is the implementation process of entrepreneurs from wealth accumulation to realize the value of life. The power of example is endless. When they know other entrepreneurs can quickly grow up to be the CEO of an enterprise, entrepreneurs take to the road of their own business from employees to the boss step by step. They get success quickly from penniless to a sharp increase in wealth or even in a short time earn the first bucket of gold. Therefore, more and more students are eager to entrepreneurship. From December 2014 to March 2015, by face to face interview and network investigation,we made questionnaires to the graduates of Chongqing Technology and Business University and other universities, in which 691 effective questionnaires were taken back, $46.16 \%$ of college students have a desire for entrepreneurship but no business. Only $6.08 \%$ with entrepreneurial aspirations and being entrepreneurial. Obviously for college students entrepreneurship is attractive. However these entrepreneurs who are not confident about it due to the limited knowledge and experience are less implementation and less success. Data shows our country college students' entrepreneurial success rate of Chinese graduates is only $2 \% \sim 3 \%$, far below the average rate of entrepreneurial success [3].

\section{B. Low business level and low-tech}

Through the investigation, Zhang ()finds that a quarter of the students believe that entrepreneurship is nothing but making money, whatever career you choose[4]. Most of college students' entrepreneurship who behave irrationally and much blindness stay in low-tech and apply less their professional knowledge to business like street vendor and selling small commodities. Entrepreneurs who can not find the right entrepreneurial opportunities in their own fields pay more attention to how to get more economic benefits as soon as possible without combining with their own expertise and entrepreneurship. Hence in competition with other entrepreneurs who did not play their strengths result in lowtech and poorquality.

\section{Weak entrepreneurial ability}

Due to lack of experience, undergraduate entrepreneurship was not sensitive to the market and most college students were easier to follow the others blindly. Therefore, the opportunity was not easy to be mining and the company was not arranged and operated effectively. For the majority, university student presents strong capriciousness. Since had no long term plan and not managed the company scientifically, college students were more likely to give up as soon as the company become unprofitable. Furthermore, the the poor ability to use resources, plan project and implement led to a loose team and incompetence of leadership which restricted the development of enterprise.

\section{Entrepreneur education need to be improved}

Except for college students themselves, college students' entrepreneurship links to the lack of entrepreneur education. Firstly, their entrepreneurships mainly stay on the phase of empty talk which means theoretic knowledge is more than practices in reality. Teaching model and teaching method more focus on the input of knowledge and the role of teacher is in the center part of teaching activities. However, entrepreneur education is a comprehensive discipline, which put more emphasis on the practice by students and accumulated experience by understanding the entrepreneur knowledge. Secondly, some students not only fail to combine their professional knowledge and entrepreneurship, but also fail to understanding the relationship between entrepreneurship and professional courses well. They hold the point that starting a business by themselves means to renounce their specialized knowledge learning, which could waste their time in starting new business. They fail to find the connection between the entrepreneurship and specialized knowledge and make full use of their specialized knowledge to create business.

\section{THE BENEFIT TO EST ABLISH ONLINE ENTREPRENEURSHIP PLATFORM FOR COLLEGE ST UDENTS}

Through online entrepreneurial platform ,students could raise their interest in entrepreneurship, get aid and guidance about the practical problems in the process of entrepreneurship.

\section{A. To realize the effectiveness of entrepreneurship education}

Compared with the entrepreneurs of forties, fifties, college students, as young, educated generation in the society have numerous advantages. Firstly, they have a quick comprehension toward new things and are good at learning new knowledge from the surrounding environment, especially getting the information, knowledge from the internet. They are easy to accept new things and willing to have a try for new things they are interested in. Moreover, they have a great push to do what they want to do without being fettered by old tradition. Secondly, through studying from the primary school to college, they are equipped with systematic knowledge and specialized skill. In the age of "Internet+", much information can be obtained from the internet which is a field college students are good at. The establishing of entrepreneurship platform can provide the training of entrepreneurship knowledge, the preferential policy and choice of entrepreneurship project and anther information. By this way, it can separate itself from the traditional theoretical teaching model and at the same time can add more simulations and interesting.

\section{B. To adapt the living habit of college students}

With entering in the age of Internet, Big Data and Cloud Platform create much connection between the life of college students and the internet. The online library also becomes an important measure for college students to acquire knowledge and read on line. Moreover, they shop online, send message on line and make friends on line and so on. Internet has been penetrating the life of college students and makes their entrepreneurship no longer be confined in the reality. For example in the website of Chongqing college student entrepreneurship service, the students can get the online entrepreneurship training and education and make full use of their scattered time to accomplish the accumulation of 
entrepreneurship knowledge without being restrained by the time and space.

\section{To make up the insufficiency of real entrepreneurship practice}

In the real entrepreneurship practice, college student are required to a series of formalities to be registered and then need some money to rent a shop. What's more, they should hire a man to manage this shop, stock up goods for customer's choosing. The opening time is also rigidly restricted. However, starting business on line just requires some simple registrations and is unnecessary to rent a shop and hire a man. You can purchase your goods when receiving the order, which can realize the zero stock and lower the cost sharply. Beside the opening time can be stretched to 24 hours. So it can be a good way to realize the entrepreneurship through internet.

\section{CREATING A HIGH QUALITY ONLINE PLATFORM FOR COLLEGE ST UDENTS' ENTREPRENEURSHIP}

To establish an online platform for college students' entrepreneurship is in urgent need due to the multiple developments of college students. Online platform can not only realize the entrepreneurship in reality but also accomplish the space and time for extended business as well as give a full play to the advantages of college students.

\section{A. To cultivate the awareness of college students' innovation and entrepreneur}

Entrepreneurship is an advanced activity that integrated comprehensive application of knowledge and comprehensive ability. Entrepreneurship education which can foster innovation and entrepreneurship is the strategic target of cultivating talents and train more senior personnel. First, training students through an online business platform can not only jobs but also entrepreneurship. Students who have innovation consciousness will be the force of promoting China's economic development. Secondly, innovative entrepreneurship education also can promote the education reform and development of colleges and universities. In May 2015 the State Council issued the "Opinions on Deepening the Reform of Higher Education Innovation and Entrepreneurship" in which it clearly requires to develop research methods, frontier, pioneering foundation, business guidance and other as pects of the employment of compuls ory and elective courses for all students. These courses should to be included in credit management. The construction of the specialized course group of the innovation and entrepreneurship education should be progressive, organic connection and scientific and reasonable. Cultivating students' innovative undertaking consciousness is the needs of the development of times.

\section{B. Creating the culture and atmosphere of public entrepreneurship}

The entrepreneurial information could be published through online platforms such as entrepreneurial forums and entrepreneurial web. For example,universities could public the information, assess and guide entrepreneurial activities such as entrepreneurial planning competition and innovation training projects for undergraduates on these platforms... On these platforms, people could study and discuss any entrepreneurial topic ,thus they can make progress together.Therefor,entrepreneurial teams could be established more easily by people who already share the interests, ambitions and topics on the platforms.

\section{Innovating the online teaching system of entrepreneurial education}

The traditional "spoon-feeding" teaching methods emphasize the importance of teachers and theories,neglected practice and the initiative of the students which entrepreneurial education pays attention to .Entrepreneurial education also focuses on "one-on-one"and small group instruction.Thus, entrepreneurial education should better join the strength of schools and societies, which can be attained by the the online teaching system.Through the the online teaching system,entrepreneurial education would be more practical and lively, which will stimulate the students ' enthusiasmfor learning.

\section{Improving the entrepreneurial ability of undergraduates}

Entrepreneurial education is a comprehensive course, involving both tacit knowledge and professional knowledge. Graduates can get profound entrepreneurial training such as management, investment, taxation, law, logistics, marketing on the online entrepreneurial platform,which deepens and improves entrepreneurial theoretic knowledge structure for graduates. The online entrepreneurial platform improves entrepreneurial ability of graduates hugely not only by theoretic knowledge but also by effective solution to the difficulties in the entrepreneurial process.First of all,more entrepreneurial project should be imported to provide the virtual process and environment of entrepreneurship for undergraduates where undergraduates can exercise and practice.Secondly,ask experts such as technology,lawyers and venture investors to joins the entrepreneurial education to share their experience, give the assessment and guidance through the whole way of entrepreneurship.

\section{E. Constructing the online practice base for entrepreneurial graduates}

Once students get the project plan,they can receive many aspects of supports. Graduates can simulate the operation in the simulation module on this platform. Excellent projects can also be linked to successful relevant actual combat platforms through the internet,taking the "round and round micro shop" established by Chongqing municipal government for example,which is the first micro store cluster platform in China, It established in March 2015. In the first month since on line, the first batch of college students shops settled reached 157, covering 15 major categories and 1200 kinds,meanwhile,the click rate exceeded 300000 people and the direct economic benefits reached 1 million yuan. Only if the shop get through the "face to face" audit by the Communist Youth League in the schools and the real name authentication,can the shop formally permitted to settle.Besides, "Tuan Tuan micro shop"help students promote their business and expand business scale freely, relying on 
activities such as the "Create Youth", "College Students Entrepreneurship Challenge". Once shops achieve success on the incubator base, you can put the business into the real societies.

\section{F. Promoting the transformation of entrepreneurial projects of graduates}

After students combine their expertise or interest to find their business projects on business platform, they can cooperate with investors when they have the bottleneck of business due to the lack of entrepreneurial experience, the shortage of venture capital, entrepreneurial team formation problems and other issues through the platform. For example, talented entrepreneurs can set up venture capital funds to provide various forms of financial resources to support students' entrepreneurship to improve capital efficiency. It is not only provide financial support to students' entrepreneurship, but also importantly offer all kinds of resources which can assist ventures in developing rapidly, promote students' innovation entrepreneurship and integrated development based on the entrepreneur's network. help excellent entrepreneurial projects land and enter into market strongly.

\section{CONCLUSION}

In the practice of entrepreneurial education, it is meaningful to create a online entrepreneurial platform combined with students' characteristics for undergraduates which helps to cultivate the culture, ability of entrepreneurship of the undergraduates. we will take the simulation software and the simulation project as the starting point, cooperate with related technology companies, and build the perfect frame structure using the modular form. Though these entrepreneurial platforms, excellent student entrepreneurs and enterprises could be combined,which not only improve the entrepreneurial ability of students but also promote the development of small and micro enterprises.

\section{REFERENCE}

[1] China Education Online http://www.eol.cn/html/c/2014gx bys/

[2] The plan of support mechanism and implementation for Chongqing small micro enterprise (The chongqing municipal government[2014] 36)

[3] Wang Xuefeng.Research on the measures of entrepreneurship of graduates in China [J].People' Forum ,201 1(11):236-237.

[4] Zhang Ning. Investigation Research on current graduates entrepreneurship and suggestions
[J].Educational Information, 2015(4):108-110.

[5] Zhang Liang, OU Gaolin. The discussion and SWOT analysis of college students online Entrepreneurship [J]. Study of computer application in education,2011,(6):95-97

[6] Chen Guang-hua,Lin Rui-xin, Yang Ping .Research on Online Business Model about University Students [J]. Information Science,2011(12):1806-1814.

[7] Chen Na. Research on entrepreneurship education for college students based on e-commerce platform [J]. Theory and Practice of Contemporary Education,2014,(12):60-62

[8] weiming LI,chunyan LI,xiaohua DU. The construction of university students innovation and entrepreneurship platform [J]. Management observer,2015(3):109-111 